\title{
Molecular analysis indicates high levels of carabid weed seed consumption in cereal fields across Central Europe
}

\author{
Britta Frei ${ }^{1,2} \cdot$ Yasemin Guenay $^{1,3} \cdot$ David A. Bohan $^{2} \cdot$ Michael Traugott $^{1} \cdot$ Corinna Wallinger $^{3}$ (I)
}

Received: 3 October 2018 / Revised: 13 March 2019 / Accepted: 20 March 2019 / Published online: 9 April 2019

(c) The Author(s) 2019

\begin{abstract}
Carabid beetles are abundant in temperate agroecosystems and can play a pivotal role as biocontrol agents. While there is good knowledge regarding their effects on invertebrate pests in some systems, comparably little is known on the rate of seed feeding under field conditions. Molecular approaches are ideally suited for investigating carabid feeding interactions; to date, however, they have only been applied to animal prey. We sampled adult carabid beetles in organic cereal fields in three regions along a Central European transect. Regurgitates from populations of the three most common species, Poecilus cupreus, Pseudoophonus rufipes and Pterostichus melanarius, were screened for plant DNA, cereal aphids, collembolans and earthworms. The frequency of carabid individuals positive for plant DNA was high $(>70 \%)$ and independent of carabid species, sex, region and the time point of sampling. Detections for non-pest and pest prey were comparably lower, with $21.6 \%$ for collembolans, $18.1 \%$ for earthworms and $4.2 \%$ for aphids, respectively. Despite the prolonged detection period of plant DNA in carabid guts, as compared to animal prey, these first results suggest that weed seeds form an important part of the adult carabid diet. It would also lend support to the hypothesis that seed-feeding carabids are biocontrol agents of weeds, with effects of regulation on the weed seedbank that depend on behavioural and contextual factors including carabid species preferences for weed seed species, their life stage and tillage practices.
\end{abstract}

Keywords Carabidae $\cdot$ Granivory $\cdot$ Seed predation $\cdot$ Pest regulation

\section{Key messages}

- Carabid beetles are important biocontrol agents of insect pests, which can also feed on weed seeds and alternative non-pest invertebrate prey.

Britta Frei and Yasemin Guenay: Joint first co-authorship.

Corinna Wallinger

Corinna.wallinger@uibk.ac.at

1 Mountain Agriculture Research Unit, Institute of Ecology, University of Innsbruck, Technikerstraße 25, 6020 Innsbruck, Austria

2 Agroecologie, AgroSup Dijon, INRA, Université Bourgogne Franche-Comte, 21000 Dijon, France

3 Institute of Interdisciplinary Mountain Research, IGF, Austrian Academy of Sciences, Technikerstraße 21a, 6020 Innsbruck, Austria
- Information on the relative frequency (level) of predation within agricultural fields between these prey groups is missing

- We investigated the level of consumption of these food types in cereal crops by three common carabid beetle species across three sampling regions in Central Europe using molecular trophic approaches.

- High levels of plant DNA detection (>70\%), independent of carabid species, sex, region and season, would indicate that weed seeds are important food resources for carabids and support the hypothesis that they have the potential to regulate the weed seed bank.

\section{Introduction}

Carabids are a diverse group of beetles that have been widely studied as biocontrol of pests such as aphids (Lang 2003; Staudacher et al. 2016; Roubinet et al. 2017), slugs (Bohan et al. 2000; Symondson et al. 2002; Thomas et al. 2009; Fusser et al. 2016; El-Danasoury et al. 2017) and 
a variety of other pests (Sunderland 2002). Moreover, several carabid species are known to consume substantial amounts of weed seeds (Tooley and Brust 2002; Honek et al. 2003; Talarico et al. 2016). Seeds are a food source extremely rich in many nutrients that are important to carabid development and reproduction, often equalling or even exceeding the quantities present in animal prey (Lundgren 2009). Moreover, weed seed predation has the potential to reduce the need for herbicides. Recent work on carabids in this context suggests that sufficiently high numbers of carabids could regulate weeds (Westerman et al. 2003; Bohan et al. 2011; Kulkarni et al. 2015; Quinn et al. 2016; Rusch et al. 2016; Petit et al. 2017).

Conclusions about the dietary choice of carabids within fields are mainly drawn from correlative analyses because trophic interactions among arthropods are, in general, difficult to observe (Symondson 2012). The few studies that have simultaneously monitored weed seed predation and carabid communities reveal that any observed correlations are highly variable and dependent upon the agricultural context (Saska et al. 2008; Davis and Raghu 2010; Jonason et al. 2013; Trichard et al. 2013). Conclusions from laboratory-based choice tests of carabid food preferences (Lundgren 2009) do not allow estimation of in-field frequencies of interaction (Loughridge and Luff 1983; Wallinger et al. 2015). Thus, direct detection of weed seed consumption is needed to understand seed-carabid interactions and mechanisms behind the biological control of weeds. DNAbased methods are reliable tools in trophic ecology for identifying food remains within dietary samples that cannot be assigned by traditional methods of dietary analysis. Only recently these have been used to identify consumed seeds in carabid regurgitates (Wallinger et al. 2015; Sint 2018). Diagnostic multiplex PCR allows testing for a defined set of food taxa in parallel within one single reaction and is especially useful for screening large numbers of samples, as it is both time- and cost-effective (Sint 2012). Recently, such assays have been successfully applied to prey choice in invertebrate food webs including carabids in cereal fields (Roubinet et al. 2017, 2018; Staudacher et al. 2018). In these studies, no feeding interactions were identified for about $45 \%$ of the arthropod predator individuals early in the season and $28 \%$ at the late period. An average of $38 \%$ of carabids were found not to have consumed prey that they were tested for (Staudacher et al. 2016). Similar observations have been made in a field study on the effects of fertilization on food webs in cereal fields in Austria (Manzl 2016), where about 44\% of the generalist predators ( $72 \%$ of these were carabids) tested negative for animal prey. One potential explanation for these high fractions of carabids testing negative for animal prey is that these individuals were consuming other prey that had not been targeted in their PCR assays and in particular weed seeds.
To date, however, this hypothesis of alternative prey has not been tested.

The present analysis compares the population frequencies of carabid consumption of plants, insect pests and alternative invertebrate prey. We investigated the dietary choice of adult carabids in organic cereal fields across a Central European transect, across three regions from Burgundy (France), through Tyrol (Western Austria) to the Vienna Basin (Eastern Austria). Over 1200 regurgitate samples of three highly abundant European carabid species were collected in six fields per region were analyzed. Samples were screened for DNA of plants, three species of cereal aphids and detritivorous non-pest prey groups (lumbricids, collembolans). The aim of the study was to: (i) evaluate the population level frequency of consumption of the different prey types, and to test whether the patterns are consistent among (ii) different carabid species, (iii) regions and (iv) the season.

\section{Materials and methods}

Six organic cereal fields each, in three different regions, were selected along an east-west transect in Central Europe, comprising different climatic and ecological conditions (Frei 2018). The first region was in central Burgundy (France) near Dijon, the second in Tyrol (Western Austria) and the third in the Vienna Basin (Eastern Austria). The field sizes varied from 1 to 30 ha. Field work was conducted in 2016 during two sampling sessions: May/June and July/August. The sampling design included four, $32 \mathrm{~m}$ long transects per field, one on each field border, where a set of different trap types was installed at a distance of 4, 8, 16 and $32 \mathrm{~m}$ from the field margin. The trapping of the carabids for molecular analysis was done with dry pitfall traps, consisting of plastic funnels (Ø $7.5 \mathrm{~cm}, 11 \mathrm{~cm}$ in depth) with inserted plastic beakers, partly filled with wood chips and covered by metal roofs. The wood chips provided structure in the plastic pitfalls that has been found to reduce intraguild predation. Traps were kept activated for $48 \mathrm{~h}$ and emptied every $12 \mathrm{~h}$ (morning and evening). Adult carabid beetles were collected alive and put individually in reaction tubes. Beetles were stimulated to regurgitate as described in Wallinger et al. (2015), sexed, identified to species level (Müller-Motzfeld 2004) and thereafter released back into agricultural fields. Beetles that died were immediately frozen at $-24{ }^{\circ} \mathrm{C}$ to provide whole body extracts. Regurgitates were used preferentially and whole body extracts were only used where there were not enough regurgitates. We selected Poecilus cupreus, Pseudoophonus rufipes and Pterostichus melanarius, which are among the most dominant carabid species in European arable land (Thiele 1977; Luff 2002) and the most abundant ones in our samples. Seed feeding does occur in all three carabids (Holland 2002; Tooley and Brust 2002; Honek 
et al. 2007; Talarico et al. 2016), although $P$. cupreus and $P$. melanarius are described as predominantly carnivorous (Thiele 1977).

DNA extraction of the regurgitates followed Wallinger et al. (2015). Whole beetles were homogenized with glass beads $(10 \times \varnothing 3 \mathrm{~mm}$ and $5 \times \varnothing 5 \mathrm{~mm}), 400 \mu \mathrm{l} 1 \mathrm{xTES}$ buffer and $10 \mu \mathrm{l}$ Proteinase K $(20 \mathrm{mg} / \mathrm{ml})$ via Precellys ${ }^{\circledR}$ 24 tissue homogenizer (Bertin Technologies, Montignyle-Bretonneux, France), at $5000 \mathrm{rpm}$ for $2 \times 60 \mathrm{~s}$ prior to incubation for lysis. Samples were screened with a diagnostic multiplex PCR assay, specifically targeting DNA of the three cereal aphid species Metopolophium dirhodum, Rhopalosiphum padi and Sitobion avenae, as well as collembolans and lumbricids. For detection of weed seeds, a general plant primer pair targeting chloroplast DNA was added. The $10 \mu \mathrm{l}$ reactions contained $2.5 \mu \mathrm{l}$ DNA extract, $0.5 \mu \mathrm{g}$ BSA, $5 \mu \mathrm{l} 2 \mathrm{xKAPA} 2 \mathrm{G}$ (KAPA Biosystems, Wilmington, MA, USA), $1 \mu$ PCR-grade water and $1 \mu$ primer mix in their respective concentrations (Table 1). The PCR conditions were: $95{ }^{\circ} \mathrm{C}$ for $3 \mathrm{~min}$, followed by 35 cycles of $95{ }^{\circ} \mathrm{C}$ for $15 \mathrm{~s}$ for denaturation, $62.5^{\circ} \mathrm{C}$ for $90 \mathrm{~s}$ for annealing, $72{ }^{\circ} \mathrm{C}$ for $30 \mathrm{~s}$ extension and $72{ }^{\circ} \mathrm{C}$ for $10 \mathrm{~min}$ for the final elongation. Within each PCR, there was one negative control (PCR-grade water) and one positive control (DNA mix of target species) included to check for DNA carryover contamination and amplification success. All PCR products were analysed using the QIAxcel capillary electrophoresis system (Qiagen) as described in Wallinger et al. (2015), with the exception that the method AM3201 was used.

Food DNA detection rates were tested for significant differences between carabid species, regions, sampling sessions and between males and females, using a generalized linear mixed model (GLMM) with the binomial distribution family and logit link. To control for false discovery due to multiple testing, Benjamini-Hochberg corrected post hoc tests were used with bound optimization by quadratic approximation. As the samples collected within fields, across transects within fields and traps within transects are not independent, a nested random effect accounting for location was introduced to the model. Differences between first versus second sampling session could only be attempted for $P$. cupreus because $P$. rufipes and $P$. melanarius were both absent at the first sampling session. The analysis presented for these two autumn breeders was therefore restricted to the second sampling session. Statistical analysis was conducted in $\mathrm{R}(\mathrm{R}$ Core Team 2017) version 1.1-17 using the package lme4.

\section{Results}

Out of all 1188 samples tested (1069 regurgitates, 119 whole beetle extracts), $78 \%$ was tested positive for at least one of the targeted food types: plants, aphids, earthworms and collembolans. The model estimated detection rates for any food
Table 1 Primers used in the multiplex PCR assay for selected prey taxa. Provided are the targeted taxa/species, the original primer names, the primers' sequences, the fragment length amplified by each primer pair, the targeted gene, the final concentration (Conc.) of each primer in the PCR and the references where primers have first been described

\begin{tabular}{|c|c|c|c|c|c|c|}
\hline Target group & Primer & Sequence $\left(5^{\prime}-3^{\prime}\right)$ & $\begin{array}{l}\text { Fragment } \\
\text { length } \\
\text { (bp) }\end{array}$ & Gene & Conc. $(\mu \mathrm{M})$ & References \\
\hline \multirow[t]{2}{*}{ Collembolan } & Col3F & GGACGATYTTRTTRGTTCG & 231 & $18 \mathrm{~s}$ & 0.2 & Kuusk and Agusti (2008) \\
\hline & A415-springt & GAATTTCACCTCTAACGTCGCAG & & $18 \mathrm{~s}$ & 0.2 & Staudacher et al. (2016) \\
\hline \multirow[t]{2}{*}{ Lumbricids } & S408-earthw & $\begin{array}{l}\text { CCATGATTTCTTAGATCGTACAAT } \\
\text { CC }\end{array}$ & 85 & $18 \mathrm{~s}$ & 0.2 & Staudacher et al. (2016) \\
\hline & A413-earthw & ATARGGGTCGGAGCTTTGTG & & $18 \mathrm{~s}$ & 0.2 & Staudacher et al. (2016) \\
\hline \multirow[t]{2}{*}{ Metopolophium dirhodum } & Met-dir-S436 & $\begin{array}{l}\text { CCTTTATCAAATAACATTGCACAT } \\
\text { AAC }\end{array}$ & 105 & $\mathrm{COI}$ & 0.2 & Ye et al. (2017) \\
\hline & Met-dir-A440 & $\begin{array}{l}\text { AATAAAGTTAATTGCTCCTAAAAT } \\
\text { TGAG }\end{array}$ & & $\mathrm{COI}$ & 0.2 & Ye et al. (2017) \\
\hline \multirow[t]{2}{*}{ Rhopalosiphum padi } & Rho-pad-S440 & $\begin{array}{l}\text { TAATAATATAAAATTAAACCAAAT } \\
\text { TCCATTA }\end{array}$ & 136 & $\mathrm{COI}$ & 0.2 & Ye et al. (2017) \\
\hline & Rho-pad-A442 & $\begin{array}{l}\text { TGATGTATTTAAATTACGATCAGT } \\
\text { AAGAAG }\end{array}$ & & COI & 0.2 & Ye et al. (2017) \\
\hline \multirow[t]{2}{*}{ Sitobion avenae } & Sit-ave-S433 & $\begin{array}{l}\text { TCATCACTTAGAATTCTTATTCGT } \\
\text { CTT }\end{array}$ & 304 & $\mathrm{COI}$ & 0.1 & Ye et al. (2017) \\
\hline & Sit-ave-A438 & $\begin{array}{l}\text { AAGGTGGRTAAATAGTTCATC } \\
\text { CTGTA }\end{array}$ & & $\mathrm{COI}$ & 0.1 & Ye et al. (2017) \\
\hline \multirow[t]{2}{*}{ Plant } & g A49425 & GGGCAATCCTGAGCCAA & 200 & $\operatorname{trnL}$ & 0.2 & Taberlet et al. (2007) \\
\hline & d B49863 & GGGGATAGAGGGACTTGAAC & & $\operatorname{trnL}$ & 0.2 & Taberlet et al. (2007) \\
\hline
\end{tabular}


DNA were significantly higher in P. rufipes $(94.1 \%)$ than in P. melanarius $(75.1 \% ; p<0.001)$ and $P$. cupreus $(75.6 \%$, $p<0.001)$. For the comparison between carabid species, only samples from the second session were used due to the absence of the autumn breeders' P. rufipes and P. melanarius at the first session. There was no difference in overall food detection rates between the two sampling sessions $(p=0.492)$, regions $(p=0.74)$ or beetle sexes $(p=0.97)$. All prey types tested were present in regurgitates of each carabid species and in each region. Plant detection rates were high everywhere (Fig. 1). In $49.8 \%$ of the food positive samples, plant DNA was the only food DNA detected, in $43.1 \%$ it was plant and animal, and in $7.1 \%$ it was animal DNA alone. The model-fitted plant detection rate was significantly higher in $P$. rufipes $(90.9 \%, p>0.001)$ than in $P$. cupreus $(63.5 \%$ first and $71.4 \%$ second sampling, $p>0.001)$ and $P$. melanarius $(69.7 \%, p>0.001$; Fig. 2). Lower detection rates were recorded for pest (aphids) and non-pest prey, i.e. lumbricids and collembolans, in comparison with plant DNA (Fig. 3). There were significantly more detections of collembolan DNA in $P$. rufipes $(44.5 \%, p<0.001)$ than in $P$. melanarius $(4.7 \%, p<0.001)$ and $P$. cupreus at the second sampling date $(10.0 \%, p<0.001)$.

\section{Discussion}

The current study is a comparison of food DNA detection of plants, invertebrate pest and alternative prey within populations of three common carabid beetles in arable fields in three different European regions. Detection frequencies of plant DNA were high-across all regions independently of carabid species, sex and sampling time. We hypothesize that the plant DNA detected in regurgitates mainly originates from consumed seeds as has been demonstrated in numerous studies (Tooley and Brust 2002; Honek et al. 2003;

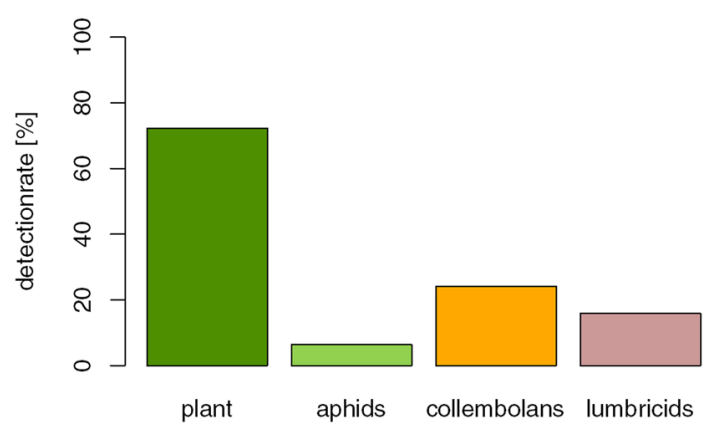

Fig. 1 Overall detection rates of prey-specific DNA in carabid regurgitates of three carabid species: Poecilus cupreus, Pseudoophonus rufipes and Pterostichus melanarius. Note: As more prey types in one sample can be detected, the total sum of all columns taken together exceeds $100 \%$

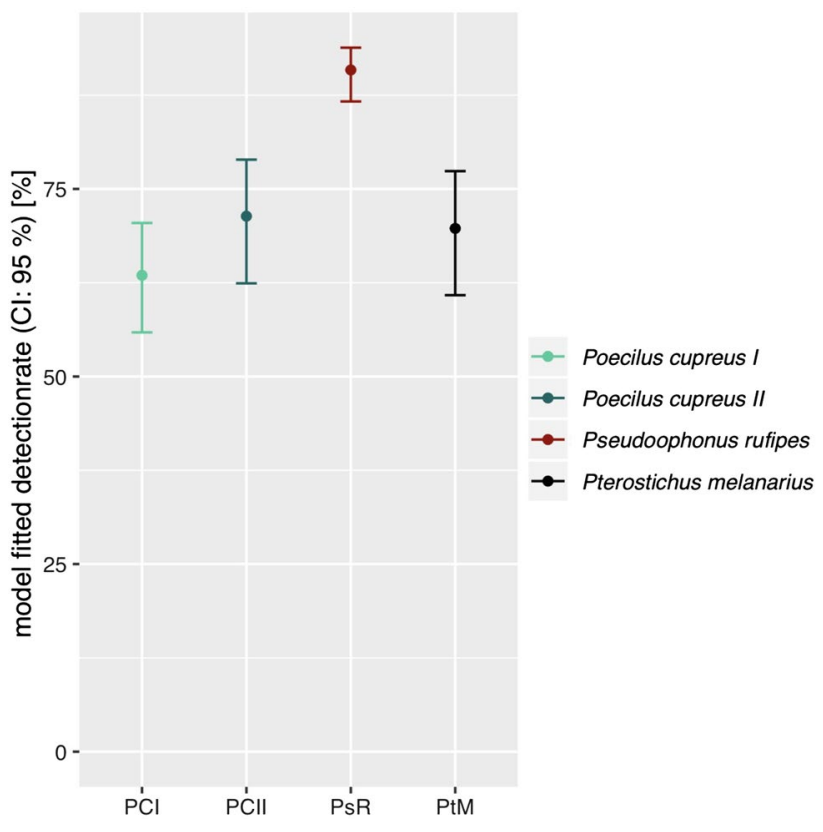

Fig. 2 Comparison of the GLMM estimated mean plant detection rates for the three carabid species: detection rates for $P$. cupreus that have been caught in the first session have been calculated separately (Poecilus cupreus I) from those stemming from the second session (Poecilus cupreus II). P. rufipes and P. melanarius were present at the second sampling session only

Lundgren et al. 2013; Daedlow et al. 2014; Kulkarni et al. 2015; Cutler et al. 2016; Talarico et al. 2016; Birthisel et al. 2017). Our logic for this hypothesis is that while carabid beetles can eat fruit, pollen and sometimes plant leaves (Toft 2002), previous studies have shown that herbivory (i.e. the consumption of other plant tissue than seeds) is negligible (Goldschmidt and Toft 1997). Non-reproductive plant tissue is a poor food source, being especially low in nitrogen and often containing toxic secondary compounds, in comparison with seeds. Fruits can be excluded as carabid food source in the current study, due to the absence of fruit-bearing plants in the fields at sample collection. To minimize the risk of false positives resulting from potential DNA carryover via pollen that might have been attached to the carabids surface, we have chosen a molecular marker targeting the trnLregion, a part of chloroplast DNA (cpDNA), which rarely is present in pollen. cpDNA is primarily inherited maternally and therefore a widely accepted molecular marker for seeds (McCauley et al. 2007). The high detection rates of cpDNA in field-collected regurgitates is therefore likely to be due to plant seeds, and more specifically the seeds of weeds (i.e. non-crop plants) because crop seeds were absent during the sampling periods. Admittedly, there were also some seedbearing plants at the field margins which could have been additionally eaten by carabids caught in the outer traps. To gain more insight on this, we are currently identifying the 


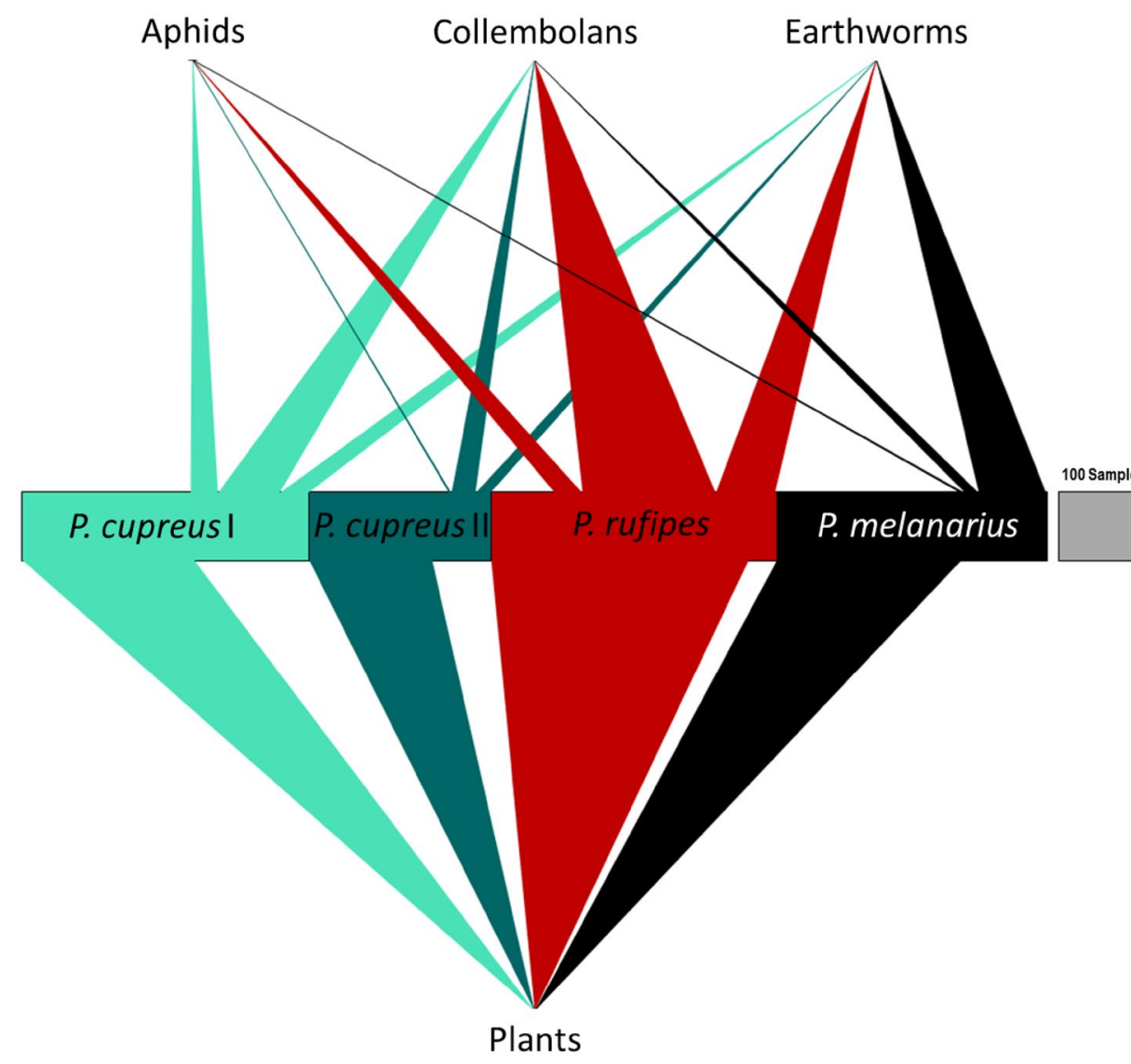

Prey Species

\section{Carabids}

Plant Food

Fig. 3 Observed prey DNA detections in regurgitates/whole body extracts of Poecilus cupreus at the first (P. cupreus $I$ ) and second sampling session (P. cupreus II), Pseudoophonus rufipes and Pterostichus melanarius across all regions. The circles stand for the different food

consumed seeds on a species-specific level via a metabarcoding approach.

Although it was already known that many carabids do consume seeds, the high proportion of field-caught beetles that were positive for plant DNA was striking. While the relative frequencies of seed consumption may be overestimated due to longer post-feeding detection intervals of plant food compared to animal prey (Staudacher et al. 2011; Sint 2018), our findings lend support to the hypothesis that seedfeeding adult carabids are significant consumers of weed seeds (Bohan et al. 2011; Kulkarni et al. 2015; Quinn et al. 2016; Rusch et al. 2016; Petit et al. 2017).

The examination done here is restricted to adult beetles because soil-living carabid larvae are poorly trapped by the pitfall trap methodology we employed. Based on laboratory studies, carabid larvae have been reported to consume substantial amounts of seeds. Some species including P. rufipes are known to build seed caches (Thiele 1977; Hartke et al. 1998; Lundgren et al. 2009), and some carabid larvae require weed seeds to complete their development (Saska and Jarosik 2001; Saska 2005, 2015). Future studies may types-i.e. aphids, collembolans and earthworms (above) and seeds (below). The width of each panel represents number of samples analysed, and width of grey boxes on the right end of each graph represents a reference number of 100 samples

shed light into the seed consumption of field-collected larvae using molecular approaches.

Among the populations of the three carabid species, $P$. rufipes showed an especially high frequency of detection for seeds. This finding is in accordance with the prior trophic characterization of this carabid species as a seed predator (Thiele 1977; Holland 2002) and laboratory feeding experiments that indicate that seeds are their preferred food source (Toft 2002; Cutler et al. 2016).

All food types that were present in populations of each carabid species in each region fit with their omnivorous feeding nature and confirm previous studies revealing the broad diet range of the three species (Toft 2002; Lundgren et al. 2009). The $22 \%$ of samples without any food detection were predominantly $P$. cupreus and P. melanarius (only $6 \%$ of these negatives were $P$. rufipes). Our multiplex PCR system did not target all possible prey, and these beetles may have consumed other prey food items. Given that $P$. cupreus and $P$. melanarius also showed significantly less prey detection in general, it is likely that we missed certain prey types that are important food, i.e. dipterans, thrips and intraguild prey, 
such as other carabid species or spiders. Low levels of predation on aphids, in comparison with other studies in European cereal fields (Staudacher et al. 2016; Roubinet et al. 2017, 2018), may be ascribed to the fact that there were only few aphids present in the sampled fields. Spontaneously high detections of aphids as food in individual fields would tend to support their potential as aphid biocontrol agents (Harwood and Obrycki 2005). Overall detection rates of lumbricid and collembolan alternative prey were higher than in Staudacher et al. (2016) and lower than in Roubinet et al. (2017, 2018). However, in concurrence with our results, these studies revealed a preference for lumbricids over collembolans in $P$. cupreus and P. melanarius and the reverse preference in $P$. rufipes.

For biocontrol, consumption rates are a key variable of interest. This parameter represents the amount of food taken in relation to its availability in the field, per standardized unit of time. Therefore, comparing molecular prey detection rates with prey availability is the next logical development of our work. However, it is not straightforward to quantify predation rates by molecular gut content analysis (Birkhofer et al. 2017). Still, the frequency of detecting specific food taxa in a large sample of consumers can provide a good proxy for the strength of specific trophic interactions and also for the amount of food consumed (Baker et al. 2014; Deagle 2018). Based on this, our findings provide a strong indication that seeds are highly frequently consumed by the investigated carabid species, potentially surpassing the consumption of animal prey.

\section{Conclusion}

The present study contributes to a better understanding of the consumption of plant and animal prey by three dominant carabid species in European arable land. By revealing high frequencies of plant consumption in cereal fields across Central Europe, our findings point to the importance of weed seeds in the diet of adult carabids. The gut content analyses also corroborate recent field studies demonstrating the importance of carabids as biocontrol agents not only for invertebrate pests but also for weeds. In the future, more insight is needed into the magnitude and importance of the effect and finding agricultural management practices that enhance or augment carabid weed seed predation and regulation.

\section{Author contributions}

M.T., D.B. and C.W. conceived and designed the study. C.W., M.T., B.F., Y.G. and D.B. performed the field sampling. Y.G. and B.F. were responsible for the molecular work. B.F analysed the data and contributed together with Y.G. to the first draft. C.W. wrote the manuscript, which all authors revised and finally approved to be published.

Acknowledgements Open access funding provided by Austrian Science Fund (FWF). For their valuable assistance in the field and regurgitate collection, we thank Luc Biju-Duval, Sarah Geiger, Kelly Kieffer, Alexandra Kurath, Anna Mederle, Diane Neu, Christine Rossetti, Tobias Wallinger and Christiane Zeisler. We are also grateful to the farmers that provided access to their fields in Burgundy, Tyrol and Vienna.

Funding Financial support was provided by the project 'Trophic assessment of ecosystem services provided by carabid beetles in agricultural land' financed by the Austrian Science Fund FWF (P28578-B25).

\section{Compliance with ethical standards}

Ethical approval All applicable international, national and institutional guidelines for the care and use of animals were followed.

Open Access This article is distributed under the terms of the Creative Commons Attribution 4.0 International License (http://creativeco mmons.org/licenses/by/4.0/), which permits unrestricted use, distribution, and reproduction in any medium, provided you give appropriate credit to the original author(s) and the source, provide a link to the Creative Commons license, and indicate if changes were made.

\section{References}

Baker R, Buckland A, Sheaves M (2014) Fish gut content analysis: robust measures of diet composition. Fish Fish 15:170-177

Birkhofer K, Bylund H, Dalin P, Ferlian O, Gagic V, Hambäck PA, Klapwijk M, Mestre L, Roubinet E, Schroeder M (2017) Methods to identify the prey of invertebrate predators in terrestrial field studies. Ecol Evol 7:1942-1953

Birthisel S, Gallandt E, Jabbour R, Drummond F (2017) Habitat and time are more important predictors of weed seed predation than space on a diversified vegetable farm in Maine, USA. Weed Sci 63:916-927

Bohan D, Bohan A, Glen D, Symondson W, Wiltshire C (2000) Spatial dynamics of predation by carabid beetles on slugs. J Anim Ecol 69:367-379

Bohan D, Boursault A, Brooks D, Petit S (2011) Nationale-scale regulation of the weed seedbank by carabid predators. J Appl Ecol 48:888-898

Cutler C, Astatkie T, Chahil G (2016) Weed seed granivory by carabid beetles and crickets for biological control of weeds in commercial lowbush blueberry fields. Agric For Entomol 18:390-397

Daedlow D, Westerman P, Baraibar B, Rouphael S, Gerowitt B (2014) Weed seed predation rate in cereals as a function of seed density and patch size, under high predation pressure by rodents. Weed Res 54:186-195 
Davis A, Raghu S (2010) Weighing abiotic and biotic influences on weed seed predation. Weed Res 50:402-412

Deagle B, Thomas A, McInnes J, Clarke L, Vesterinen E, Clare E, Kartzinel T, Eveson J (2018) Counting with DNA in metabarcoding studies: how should we convert sequence reads to dietary data? Mol Ecol 0:391-406

El-Danasoury H, Cerecedo C, Córdoba M, Iglesias-Piñeiro J (2017) Predation by the carabid beetle Harpalus rufipes on the pest slug Deroceras reticulatum in the laboratory. Ann Appl Biol 170:251-262

Frei B (2018) Trophic interactions of carabid beetles in Central European cereal fields. Institute of Ecology, Innsbruck, p 40

Fusser M, Pfister S, Entling M, Schirmel J (2016) Effects of landscape composition on carabids and slugs in herbaceous and woody field margins. Agric Ecosyst Environ 226:79-87

Goldschmidt H, Toft S (1997) Variable degrees of granivory and phytophagy in insectivorous carabid beetles. Pedobiologia 41:521-525

Hartke A, Drummond F, Liebman M (1998) Seed feeding, seed caching, and burrowing behaviors of Harpalus rufipes De Geer larvae (Coleoptera: Carabidae) in the Maine potato agroecosystem. Biol Control 13:91-100

Harwood J, Obrycki J (2005) Quantifying aphid predation rates of generalist predators in the field. Eur J Entomol 102:335-350

Holland J (2002) The agroecology of carabid beetles Andover. Intercept Limited, Chennai

Honek A, Martinkova Z, Jarosik V (2003) Ground beetles (Carabidae) as seed predators. Eur J Entomol 100:531-544

Honek A, Zdenka M, Saska P, Pekar S (2007) Size and taxonomic constraints determine the seed preferences of Carabidae (Coleoptera). Basic Appl Ecol 8:343-353

Jonason D, Smith H, Bengtsson J, Birkhofer K (2013) Landscape simplification promotes weed seed predation by carabid beetles (Coleoptera: Carabidae). Landsc Ecol 28:487-494

Kulkarni S, Dosdall L, Willenborg C (2015) The role of ground beetles (Coleoptera: Carabidae) in weed seed consumption: a review. Weed Sci 63:355-376

Kuusk AK, AgustÍ N (2008) Group-specific primers for DNA-based detection of springtails (Hexapoda: Collembola) within predator gut contents. Mol Ecol Res 8:678-681

Lang A (2003) Intraguild interference and biocontrol effects of generalist predators in a winter wheat field. Oecologia 134:144-153

Loughridge A, Luff M (1983) Aphid predation by Harpalus rufipes (Degeer) (Coleoptera: Carabidae) in the laboratory and field. J Appl Ecol 20:451-462

Luff M (2002) Carabid assemblage organization and species composition. In: Holland J (Ed) The Agroecology of Carabid Beetles. Intercept Publishers, Andover, pp 41-79

Lundgren J (2009) Relationships of natural enemies and non-prey foods UK. Springer, Berlin

Lundgren J, Ellsbury M, Prischmann D (2009) Analysis of the predator community of a subterranean herbivorous insect based on polymerase chain reaction. Ecol Appl 19:2157-2166

Lundgren J, Saska P, Honěk A (2013) Molecular approach to describing a seed-based food web: the post-dispersal granivore community of an invasive plant. Ecol Evol 3:1642-1652

Manzl L (2016) The effect of fertilizer type on the diet of generalist predators in cereal crops: a molecular approach. Master Thesis, University of Innsbruck, $60 \mathrm{pp}$

McCauley D, Sundby A, Bailey M, Welch M (2007) Inheritance of chloroplast DNA is not strictly maternal in Silene vulgaris (Caryophyllaceae): evidence from experimental crosses and natural populations. Am J Bot 94:1333-1337

Müller-Motzfeld G (2004) Käfer Mitteleuropas, Bd. 2: Adephaga I: Carabidae Heidelberg. Springer, Berlin
Petit S, Trichard A, Biju-Duval L, McLaughlin Ó, Bohan D (2017) Interactions between conservation agricultural practice and landscape composition promote weed seed predation by invertebrates. Agric Ecosyst Environ 240:45-53

Quinn N, Brainard D, Szendrei Z (2016) The effect of conservation tillage and cover crop residue on beneficial arthropods and weed seed predation in acorn squash. Environ Entomol 45:1543-1551

R Core Team (2017) R: a language and environment for statistical computing. https://www.R-project.org/

Roubinet E, Birkhofer K, Malsher G, Staudacher K, Ekbom B, Traugott M, Jonsson M (2017) Diet of generalist predators reflects effects of cropping period and farming system on extra- and intraguild prey. Ecol Appl 27:1167-1177

Roubinet E, Jonsson T, Malsher G, Staudacher K, Traugott M, Ekbom B, Jonsson M (2018) High Redundancy as well as complementary prey choice characterize generalist predator food webs in agroecosystems. Sci Rep 8:8054

Rusch A, Binet D, Delbac L, Thiéry D (2016) Local and landscape effects of agricultural intensification on Carabid community structure and weed seed predation in a perennial cropping system. Landsc Ecol 31:2163-2174

Saska P (2005) Contrary food requirements of the larvae of two Curtonotus (Coleoptera: Carabidae: Amara) species. Ann Appl Biol 147:139-144

Saska P (2015) Seed requirements and consumption of Amara montivaga, a granivorous carabid (Coleoptera: Carabidae). Acta Soc Zool Bohem 79:121-125

Saska P, Jarosik V (2001) Laboratory study of larval food requirements in nine species of Amara (Coleoptera: Carabidae). Plant Prot Sci 37:103-110

Saska P, Van der Werf W, de Vries E, Westerman P (2008) Spatial and temporal patterns of carabid activity-density in cereals do not explain levels of predation on weed seeds. Bull Entomol Res 98:169-181

Sint D, Raso L, Traugott M (2012) Advances in multiplex PCR: balancing primer efficiencies and improving detection success. Methods Ecol Evol. https://doi.org/10.1111/j.2041-1210x.2012.00215.x

Sint D, Guenay Y, Mayer R, Traugott M, Wallinger C (2018) The effect of plant identity and mixed feeding on the detection of seed DNA in regurgitates of carabid beetles. Ecol Evol, in press

Staudacher K, Wallinger C, Schallhart N, Traugott M (2011) Detecting ingested plant DNA in soil-living insect larvae. Soil Biol Biochem 43:346-350

Staudacher K, Jonsson M, Traugott M (2016) Diagnostic PCR assays to unravel food web interactions in cereal crops with focus on biological control of aphids. J Pest Sci 89:281-293

Staudacher K, Rennstam Rubbmark O, Birkhofer K, Malsherd G, Sint D, Jonsson M, Traugott M (2018) Habitat heterogeneity induces rapid changes in the feeding behaviour of generalist arthropod predators. Funct Ecol 32:809-819

Sunderland CD (2002) Invertebrate pest control by carabids. In: Holland JM (ed) The agroecology of carabid beetles. Intercept Publishers, pp 165-214

Symondson W (2012) The molecular revolution: using polymerase chain reaction based methods to explore the role of predators in terrestrial food webs pp. In: Gurr G, Wratten S, Snyder W, Read $\mathrm{D}$ (eds) Biodiversity and insect pests: key issues for sustainable management. John Wiley \& Sons, Chichester, pp 166-184

Symondson W, Glen D, Ives A, Langdon C, Wiltshire C (2002) Dynamics of the relationship between a generalist predator and slugs over five years. Ecology 83:137-147

Taberlet P, Coissac E, Pompanon F, Gielly L, Miquel C, Valentini A, Vermat T, Corthier G, Brochmann C, Willerslev EE (2007) Power and limitations of the chloroplast trnL (UAA) intron for plant DNA barcoding. Nucleic Acids Res 35:14-21 
Talarico F, Giglio A, Pizzolotto R, Brandmayr P (2016) A synthesis of feeding habits and reproduction rhythm in Italian seedfeeding ground beetles (Coleoptera: Carabidae). Eur J Entomol $113: 325-336$

Thiele H-U (1977) Carabid beetles in their environments: a study on habitat selection by adaptation in physiology and behaviour. Springer, Berlin

Thomas R, Harwood J, Glen M, Symondson W (2009) Tracking predator density dependence and subterranean predation by carabid larvae on slugs using monoclonal antibodies. Ecol Entomol 34:569-579

Toft S, Bilde T (2002) Carabid diets and food value. In: Holland JM (ed) The Agroecology of Carabid beetles. Intercept Publications, Andover, pp 81-110

Tooley J, Brust G (2002) Weed seed predation by carabid beetles. In: Holland H (ed) The Agroecology of Carabid Beetles. Intercept Publications, Andover, pp 215-229

Trichard A, Alignier A, Petit S (2013) The relative contribution of local management and landscape context on weed seed predation service. Basic Appl Ecol 14:235-245
Wallinger C, Sint D, Baier F, Schmid C, Mayer R, Traugott M (2015) Detection of seed DNA in regurgitates of granivorous carabid beetles. Bull Entomol Res 105:728-735

Westerman P, Wes J, Kropff M, Van der Werf W (2003) Annual losses of weed seeds due to predation in organic cereal fields. J Appl Ecol 40:824-836

Ye Z, Vollhardt IMG, Girtler S, Wallinger C, Tomanovic Z, Traugott M (2017) An effective molecular approach for assessing cereal aphid-parasitoid-endosymbiont networks. Sci Rep 7:3138

Publisher's Note Springer Nature remains neutral with regard to jurisdictional claims in published maps and institutional affiliations. 